\title{
Research on the Paths of Cultural Education in College English Teaching
}

\author{
Rongrong Pan ${ }^{1, *}$, Min Yang ${ }^{1}$ and Lirui Duan ${ }^{1}$
}

\author{
${ }^{1}$ Foreign Language School, Kunming University, Kunming, Yunnan 650214, China \\ * Corresponding author. Email: 15925110915@163.com
}

\begin{abstract}
This paper takes cultural education in college English teaching as the research object, exploring the effective paths to integrate cultural education in the college English teaching process. Based on in-depth literature research and interviews, the study first illustrated the significance of cultural education in college English teaching. Language teaching is an important carrier of cultural transmission and a bridge of intercultural communication. After analyzing the current problems of cultural education in college English teaching, four suggested paths were proposed to create a multi-channel teaching model, build a multilateral curriculum system, strengthen the literacy of traditional Chinese culture and cultivate students' multicultural awareness. The findings will provide possible ways to integrate cultural education into college English teaching and cultivate a new generation with Chinese spirit, international vision and cross-cultural communication skills.
\end{abstract} Keywords: English Teaching; Cultural Education; All-round Education; Chinese Culture

\section{INTRODUCTION}

Cultural education is a kind of educational mode that people are influenced imperceptibly in the cultural atmosphere by melting the educational content through various cultural forms or carriers. Cultivating people by culture is a systematic process that includes such elements as what kind of culture should be applied, how to educate people with culture and what kind of person were cultivated to be. Under the background of the new era, the task of cultural education in colleges and universities is to train the new generation who is taking on the important mission of national rejuvenation by "the socialist culture with Chinese characteristics" imperceptibly. [1] It is an effective way to carry out the fundamental task of morality education.

At the 2016 National Ideological and Political Conference of Colleges and Universities, the General Secretary Xi put forward the goal of "Three-wide Education," which is to educate people in the whole process, in all aspects and in all stages of education. All-round education requires ten channels of joint efforts to form a comprehensive education strategy with "Morality Education" as the core. At the National Education Conference in September 2018, Xi made another important instruction: we should work hard to strengthen our ideals and convictions, cultivate patriotism and strengthen moral cultivation. The two important speeches come down in one continuous line. Their connotation is to emphasize the important position of ideological education in higher education, and all educational activities should be designed around the goal of "morality education". Former Minister of Education Yuan Guiren also proposed at the inaugural meeting of the University Cultural Research and Development Center: "In essence, the process of education and teaching in universities is a purposeful and planned cultural process. The so-called education by teaching, management, service and environment, in the final analysis, are all cultural education". [2] It can be seen that cultural education is an important duty and necessary way to carry out quality-oriented education scientifically.

At present, domestic scholars focus on three major research directions: the function, mode and paths of university cultural education; [3] the combination of foreign language curriculum and mother tongue cultural education; [4] National cultural interests and language teaching policy research. By combing the relevant literature, it shows that there are less status quo investigation and analysis based on empirical research and more theoretical research from the research methods. From the research platform or model, most of the existing cultural education research focuses on morality education in ideological and political courses, especially the inadequate combination of mother tongue culture and foreign language teaching. From the perspective of research, it is mainly reflected in cultural ideology, national cultural interests and security, and the importance of mother tongue culture. Therefore, due to the weak awareness of integrating cultural education with curriculum, the lack of Chinese traditional culture education is common in most universities. The research of Yunnan universities is still in the initial stage, and the research results of culture-oriented education model based on curriculum are scarce. It is an important task for college English course to combine language teaching with cultural education. 


\section{THE SIGNIFICANCE OF CULTURAL EDUCATION IN COLLEGE ENGLISH TEACHING}

The function of university is essentially the enlightenment, inheritance and innovation of culture. [5] College English as a foundational discipline, has its own unique cultural function which lies in its characteristics of interdisciplinary, cultural diversity and cross-cultural nature. The educational value of English is mainly through English teaching to meet the needs of students' own development, so that students learn, master and use English knowledge and skills. Meanwhile, students' learning interest and ability get continuously enhanced and their humanistic quality, quality of active learning together with social responsibility are constantly improved. Finally, they become a new generation with Chinese spirit, international vision and cross-cultural communication skills.

\subsection{Language Teaching is an Important Carrier of Cultural Transmission}

As an important carrier of culture, language and culture are inseparable. In the book Context and Culture in Language Teaching, the famous linguist Claire Kramsch pointed out: "Language expresses, carries and symbolizes cultural reality, the two are inseparable."[6] Culture and language influence each other, restrict each other and promote each other. Culture teaching plays an important role in language teaching. College English course, as a language course, should not only carry the task of teaching English as a universal language, but also integrate cultural transmission into it. Without teaching of culture, the course will lose the soul and root just left with empty words and meaningless symbols. [7]

Every college student may become an emissary of Chinese culture to the people of other countries in the future. University period is a golden period for students to form and establish their outlook on life, values and world outlook. In this period, students have a strong desire for knowledge. They have a strong ability to explore, understand and accept new things, but they also lack a certain ability to identify diverse social cultures. As a part of "all-round education", teaching and cultural education is the mission that college teachers need to shoulder in the front line of teaching. Therefore, as a teacher, we should not be limited to the dissemination of knowledge in teaching but should infiltrate cultural education into all links of teaching.

\subsection{Language Teaching is a Bridge of Intercultural Communication}

College English, as a cross-cultural teaching course, not only has the educational function of humanities, but also is the carrier of understanding two civilizations and accepting two cultures. In college English teaching, it is necessary to combine cultural comparison to make students understand the cultural backgrounds and moral standards of both China and the west, so that students can have a clear moral concept in the complex social phenomena. They can restrain themselves with appropriate moral norms in social life and have the courage to bear social responsibilities.

There is no doubt that foreign language teaching plays an important role because of its unique cross-cultural and communicative characteristics. In foreign language teaching in colleges and universities, it is necessary to transform the traditional single-machinery education into rich and creative cultural edification. Students should strengthen their own cultural awareness to be qualified "global citizens," and carry forward their own excellent traditional culture. This is the essence of the educational function of college English teaching culture.

In college English classroom, we should provide students with a dynamic space for ideological collision, so that students can obtain extensive spiritual exchange and value sharing. College English curriculum should be based on cultivating students to respect and understand the cultural diversity of the world with an open mind. They should establish the cultural values of equality and pluralism, possess international vision and global consciousness, and be qualified citizens of the globe. At the same time, in the cross-cultural communication, in the process of multicultural collision, carry forward and reconstruct the national culture, take on the dissemination and promotion of Chinese culture, and improve the impact of China's cultural mission.

\section{CURRENT SITUATION OF CULTURAL EDUCATION IN COLLEGE ENGLISH TEACHING}

The content of language and culture teaching should include not only understanding the target language culture, but also highlighting the mother tongue culture and realizing the purpose of cross-cultural communication. However, foreign language teaching in colleges and universities unilaterally pursues the certificate value and tool value of language and ignores its cultural value, which leads to teachers' weariness of teaching and students' weariness of learning. Its essence of cultural education is seriously distorted. According to the online questionnaire survey conducted in three universities in Yunnan, college English teaching reform has been implemented in Yunnan for many years, and various teaching models and teaching methods have been promoted one after another. Colleges and universities vigorously carry out the discussion of "student-centered" educational thought, guide the whole schoolteachers to change educational ideas, actively carry out teaching reform, and the reform has achieved initial results. However, in the process of reform, some existing problems still there, like stubborn diseases, and new problems continue to appear, which have a certain universality. 


\subsection{Weak Awareness of Cultural Education in the Process of Language Teaching}

With the advancement of globalization, the society generally requires college graduates to have a certain English ability, and English is becoming more and more "instrumental". In order to prove that college graduates have the corresponding English ability, English proficiency test came into being. College students are flocking to English level tests, and employers are also cherishing all kinds of English level certificates. In this social environment, teachers and students regard classroom teaching as a simple way to "obtain English Certificate", thus ignoring its function and role of cultural education. English cannot play its cultural and communication functions as a world language, which eventually leads to the lack of its cultural education function.

Some language teaching is divorced from culture and classroom teaching is very boring. Some classrooms blindly emphasize western culture, so that mother tongue culture is often ignored in foreign language teaching, and the phenomenon of mother tongue culture aphasia is more common. At present, in the university curriculum, the concept of "cultural education" relying on the curriculum is not emphasized. Teachers generally regard reading and correcting homework as the whole connotation of teaching and educating people, which is actually a narrow understanding of teaching. To change the above dilemma, it is a path worth exploring to combine foreign language teaching with Chinese cultural elements.

\subsection{Single College English Teaching Mode}

At present, among the main teaching methods adopted by College English teachers, less than half of the students think that teachers adopt the discussion and heuristic teaching mode, accounting for about $44.81 \%$. Most classroom teaching modes are teacher led indoctrination, and students' participation in classroom activities is very low. In traditional foreign language teaching, teachers still pay attention to the teaching of foreign language knowledge, rarely analyze the cultural phenomena transmitted by the language, and evolve foreign language teaching into mechanical teaching. This kind of teaching mode makes the cultural edification separate from the classroom and completely ignores the cultural education function of foreign language teaching.

The curriculum structure is also single, and the curriculum is lack of coherence, which reflected in the disconnection of students' English learning and the serious shortage of interdisciplinary courses combining major and foreign language. there are few public elective courses with cross-cultural contents. Students' English learning time is decreasing, and the function of cultural education is also weakening.

\subsection{Unbalanced Cultural Contents in College English Textbooks}

In English culture teaching, we blindly emphasize the differences between Chinese and Western cultures and the cultural introduction of English-speaking countries, relatively despise the mutual infiltration and influence between Chinese and Western cultures, thus ignore the broad and profound cultural education function carried by the mother tongue. In the process of communication, carrying forward mother tongue culture is the main purpose and important content of communication activities. However, the existing foreign language textbooks in colleges and universities in China, such as New Horizon College English, New College English and new version College English, all focus on the original English articles in terms of material selection, but there are few English translations of excellent Chinese literary works to reflect the mother tongue culture. From the perspective of cross-cultural communication theory, the lack of mother tongue culture in teaching materials causes students to know little about their own traditional culture and lack the expression ability of Chinese cultural elements.

The neglect of English expression of Chinese culture in foreign language teaching will inevitably make English learners in China lose their cultural identity in international communication. College English teaching should introduce and spread Chinese culture to the world with the help of English, an international language medium, so as to realize the real cultural dialogue with other nationalities in the world.

\subsection{Insufficient Combination of Cross-cultural contents with curriculum}

Foreign language is a subject with fierce collision between Chinese and Western cultures. Understanding and adapting to different cultures is an important embodiment of cross-cultural communicative competence. Through the questionnaire survey, it is found that more than $80 \%$ of the students believe that "the cultivation of cross-cultural communicative competence has a great influence on the future career development direction", more than $47 \%$ of the students feel that "there are few courses that combine the cultivation of cross-cultural competence and speculative competence in the classroom". At present, most college English teachers have few opportunities to study and communicate abroad for a long time. Their British and American cultural knowledge and cross-cultural communication strategies are obtained through books. This indirect cultural cognition has some defects.

Moreover, due to the long-term examination-oriented education in China, most students do not have a comprehensive understanding of their own Chinese culture, and their cultural literacy is also lacking. Therefore, in the process of cross-cultural communication, how to realize the effective communication between local culture and external culture and highlight local culture is a challenge for college teachers and students. 


\section{THE SUGGESTED PATHS OF CULTURAL EDUCATION IN COLLEGE ENGLISH TEACHING}

Education is the foundation of education, and education focuses on the process of educating people. The Opinions of the CPC Central Committee and the State Council on Further Strengthening and Improving College Students' Ideological and Political Education points out that "All teachers have the responsibility of educating people." and "we should integrate ideological and political education into all links of college students' professional learning and into all aspects of teaching, scientific research and social services." Therefore, in the new situation, it is urgent to expand the function of foreign language teaching, broaden the field of teaching and education, increase the number of characteristic courses in colleges and universities, and improve the quality of international talents training. The combination of language and culture can not only make the content of college foreign language classroom teaching more meaningful and interesting, help to improve the attraction of the curriculum to students, but also help to enhance the students' cultural literacy of the East and West. At the same time, it helps enhance their adaptability of cross-cultural communication.

\subsection{Creating a Multi-channel Teaching Model}

Reforms should be advocated from the teaching content to the teaching method. To construct a college foreign language education path, it is advisable to combine language with culture, combine language with major and combine class with extracurricular.

First, combining English curriculum with culture to achieve the purpose of ideological and political education. Teachers should fully excavate and refine the Chinese excellent traditional cultural elements in the content of language points in each chapter of the course, such as Confucianism, tea ceremony spirit, food culture and other elements. It is of great importance to integrate the essence of Chinese excellent traditional culture into language teaching for teachers to spread Chinese culture, and help students establish confidence in their mother tongue culture, so as to establish correct values and ideology.

Second, combing English teaching with students' major to improve students' professional, ideological and speculative ability. The function of college English course is not only lying-in cultivating student's language ability, but also aims to enhance their comprehensive abilities concerning professional development. It's better for teachers to implement diverse additional materials related to different majors, such as medicine, gardening, history, management and so on. The single indoctrination teaching mode should be shifted into student-centered class by allowing students to input more major-related English materials, making discussions and sharing ideas. During the process, both of student's English and professional skills are greatly enhanced. Their interest and participation in class learning also get improved.

Third, combining classroom education and extracurricular practice education channels to improve students' ability of integrating theory with practice. College English class cannot be only limited in class teaching and activities. Centering on the theme of the course, the task-based teaching method is adopted to finally implement the educational achievements into the students' practical behavior.

\subsection{Building a Multilateral Curriculum System}

College English teaching should be reformed from the aspect of curriculum structure. Teachers should construct a curriculum model based on language skill education, integrate the essence of Chinese and foreign cultures and add multidisciplinary professional knowledge to expand the teaching function of English, and improve students' interest in learning and also meet the goal of talent cultivation. Formally, it not only pays attention to the infiltration of Chinese and foreign cultural information in daily teaching, but also can set up foreign language courses oriented to spread Chinese culture, help students talk about Chinese cultures in English and tell Chinese stories. In terms of content, in addition to college English compulsory courses, interdisciplinary courses with professional characteristics such as cross-cultural and professional foreign languages can be added. Traditional Chinese culture should also be added to the curriculum, so as to cultivate students' mother tongue cultural accomplishment and explore the rich connotation of mother tongue culture as far as possible. Exploring the use of English expression of Chinese unique culture in practice, including Chinese history, politics, philosophy, customs and so on, rather than just learning and studying British and American culture without mentioning domestic cultural phenomenon. The cultural elements of theoretical teaching content can be excavated and refined in the content of knowledge points in each chapter of the course, so as to help students establish correct values and explore the sustainable development path of the combination of foreign language and cultural education.

\subsection{Strengthening the Literacy of Chinese Culture}

The process of foreign language teaching is also a process of re-examining and carrying forward the national culture. As the main body of English teaching activities, both teachers and students should cultivate their mother tongue cultural awareness, improve their cultural literacy, study Chinese cultural phenomena, and master the expression of Chinese culture in English.

First of all, improving teachers' mother tongue cultural literacy. Teachers have to participate in Chinese culture training programs, so that they can improve their mother tongue cultural literacy. Teachers should not only have a 
solid foundation of English language, but also have profound Chinese cultural literacy and cultural communication ability. We should not only be the interpreter of the language, but also be the guide of the cultural journey, so as to give full play to the cultural education function of English teaching. In academic exchanges, we should not only invite foreign language and culture experts, but also invite Chinese language and culture experts to give lectures on Chinese culture, so that teachers can understand Chinese culture and improve cultural literacy.

Then, we should optimize the allocation of teaching resources. Using the Chinese traditional culture learning websites in teaching, we can purposefully explore the differences between native culture and foreign culture, explore the skills of expressing the mysteries of mother tongue culture in English, and actively study cultural countermeasures. In the compilation and selection of teaching materials, we should balance the cultural content, abandon the outright "British and American culture", properly integrate Chinese elements, enrich the teaching content of mother tongue culture, and enlarge English vocabulary to describe things with Chinese characteristics, so that students can use English to express Chinese cultures smoothly.

\subsection{Cultivating Students' Multicultural Awareness}

English teaching should strive to establish students' awareness of world citizenship, and strive to learn different cultures around the world, but also pay attention to the traditional culture of the nation. Through the study of English, when expressing Chinese culture, we can not only understand and acquire our native culture from a new cultural perspective, but also reconstruct our mother tongue culture and have a creative new understanding, so as to realize the extension of mother tongue culture. In today's world, both cultural and economic development will appear a situation of mutual penetration and complementary. Our world is increasingly showing a trend of "Great Harmony" in many fields, especially in the fields of science, technology and economy. In English teaching, establishing students' equal and diversified cultural values, cultivating students' international vision and global consciousness, guiding students to be world citizens and carrying forward their national culture are not only the essence of the educational function of English teaching culture, but also the needs of the development of the times.

\section{CONCLUSION}

As a platform to improve students' cultural skills and expand cross-cultural knowledge, English teaching should give full play to its curriculum advantages and bridge role in today's continuous improvement of China's international status. Teachers should establish students' equal and diversified cultural values, cultivate students' international vision and global consciousness, carry forward their national culture and focus on the goal of "all-round education". We should strive to cultivate real international talents with high-level language ability and cross-cultural communication ability, so that they can shoulder the mission of spreading and carrying forward Chinese culture and improving the influence of Chinese culture.

\section{ACKNOWLEDGMENT}

This research was financially supported by 2020 Scientific Research Fund Project of Yunnan Provincial Department of Education: Study on the Integration of Chinese Culture into College English Teaching under the Strategy of "Culture Going Global” Project Number: 2020J0535.

\section{REFERENCES}

[1] Wang Shouren. On the Transformation of English Education in China[J]. Foreign Language, 2016. (In Chinese)

[2] Yuan Guiren. Strengthening University Culture Research and Promoting University Culture Construction [J]. Chinese University Teaching, 2002. (In Chinese)

[3] Wang Shiye. Research on College English Teaching from the Perspective of Cultural Education Function[J]. Overseas English, 2014. (In Chinese)

[4] Cao di. Reflections on Integrating Chinese Culture into English Learning Teaching[J]. Educational exploration, 2013. (In Chinese)

[5] Hu Webzhong, Gao Yihe. Foreign language teaching and culture [M]. Changsha: Hunan Education Press, 1997. (In Chinese)

[6] Claire Kramsch. Language and Culture[M]. Shanghai: Foreign Language Education Press, 2000.

[7] BYRAM M. Cultural Studies in Foreign Language Education[M]. Multilingual Matters LTD,1989. 